\title{
Physiological response to temperature changes of the marine, sulfate-reducing bacterium Desulfobacterium autotrophicum
}

\author{
Ralf Rabus *, Volker Brüchert, Judith Amann, Martin Könneke \\ Max-Planck-Institut für Marine Mikrobiologie, Celsiusstrasse 1, D-28359 Bremen, Germany
}

Received 17 June 2002; received in revised form 29 July 2002; accepted 30 July 2002

First published online 11 September 2002

\begin{abstract}
The physiological response of bacteria to temperature is critical for the regulation of biogeochemical processes on daily, seasonal, and inter-annual time scales. We investigated the temperature response of the marine sulfate-reducing bacterium Desulfobacterium autotrophicum strain HRM2. Growth experiments in a temperature gradient block demonstrated that D. autotrophicum is psychrotolerant and grows between 0 and $31^{\circ} \mathrm{C}$. The normal range of temperature for growth is between 4 and $29^{\circ} \mathrm{C}$. The physiological response to temperature changes was studied with three sets of cells that were acclimated at 4,10 , and $28^{\circ} \mathrm{C}$, respectively. Sulfate reduction rates were determined in the temperature gradient block with short-term incubations to minimize growth. The rates were similar at the 4 and $10^{\circ} \mathrm{C}$ acclimation temperature, and exhibited an enhanced response at $28^{\circ} \mathrm{C}$. At every acclimation temperature, sulfate reduction rates increased 20 -fold from -1.7 to $41^{\circ} \mathrm{C}$. The relative proportion of cellular unsaturated fatty acids (e.g. cis $\left.16: 1\right)$ and short-chain fatty acids increased when cells were grown at $4^{\circ} \mathrm{C}$ compared to $28^{\circ} \mathrm{C}$. The proteome of D. autotrophicum strain HRM2 was studied by two-dimensional gel electrophoresis with soluble extracts of cells grown at the three respective acclimation temperatures. Protein patterns were similar with the exception of two proteins showing 5-10-fold lower abundance in the $4^{\circ} \mathrm{C}$ culture compared to the $28^{\circ} \mathrm{C}$ culture. In general, D. autotrophicum strain HRM2 responded to low temperatures by reduced metabolic activity rather than by pronounced de novo synthesis of specifically adapted enzymes. Such a strategy agrees well with in situ activities measured in field studies and may reflect a common physiological principle of psychrotolerant marine sulfate-reducing bacteria.
\end{abstract}

(C) 2002 Federation of European Microbiological Societies. Published by Elsevier Science B.V. All rights reserved.

Keywords: Sulfate-reducing bacterium; Temperature; Sulfate reduction rate; Cellular fatty acid; Two-dimensional gel electrophoresis; Desulfobacterium autotrophicum

\section{Introduction}

Temperature is an important variable for rates of bacterial growth and substrate conversion [1]. In temperate climates, in situ temperatures of shallow water sediments, in particular in the intertidal zones, can vary considerably during daily and annual cycles. For example, the annual temperature range in the Weser estuary in North Germany varies from 0 to $35^{\circ} \mathrm{C}$ ([2]; M. Böttcher, personal communication). Only psychrotolerant microorganisms are active over this temperature range. They have an optimal growth temperature above $20^{\circ} \mathrm{C}$, but are also able to grow below $5^{\circ} \mathrm{C}$ [3]. Psychrophilic microorganisms can even grow be-

\footnotetext{
* Corresponding author. Tel.: +49 (421) 2028 736; Fax: +49 (421) 2028580

E-mail address: rrabus@mpi-bremen.de (R. Rabus).
}

low $0^{\circ} \mathrm{C}$, but they cannot grow above $20^{\circ} \mathrm{C}$, and have an optimal growth temperature below $15^{\circ} \mathrm{C}$. Psychrotolerance may therefore be regarded as an important survival strategy for microorganisms in temperate marine sediments characterized by periodic changes from low to intermediate temperatures.

Coastal ranges are characterized by high organic inputs from river outlets and by high primary production [4]. Sulfate reduction may account for more than $50 \%$ of the total remineralization of organic matter in coastal marine sediments [5,6], which emphasizes the important role of sulfate-reducing bacteria in the carbon cycle for such marine systems. While the sulfate-reducing bacteria described from marine systems often differ considerably with respect to their nutritional properties, most of them have an optimal growth temperature around $25^{\circ} \mathrm{C}[7,8]$. To date only few examples of cold-active marine sulfate-reducing bacteria are known [9-12]. 
In this study, we investigated the temperature response of Desulfobacterium autotrophicum strain HRM2. The organism was isolated from marine sediment in Venice lagoon, Italy [13] and is physiologically versatile. D. autotrophicum strain HRM2 can grow autotrophically with $\mathrm{H}_{2}$ as sole source of electrons or heterotrophically with a variety of low molecular mass organic substrates such as lactate, ethanol and succinate [13]. Currently, the whole genome sequence of $D$. autotrophicum strain HRM2 is determined by the REGX consortium (www.regx.de). The presented data demonstrate that $D$. autotrophicum strain HRM2 can grow at temperatures as low as $0^{\circ} \mathrm{C}$ and may therefore be regarded as a model organism for psychrotolerant marine sulfate-reducing bacteria in temperate climate zones.

Psychrotolerant microorganisms implement several strategies at different molecular levels in order to adapt to transitions between low and intermediate temperatures. Low temperatures exert thermodynamic constraints on the biochemical machinery of the cell affecting the kinetic properties of enzymes by structural destabilization [14]. These may be overcome by either generally synthesizing proteins that are functional over a wider range of temperatures or by de novo synthesis of specifically cold-adapted enzymes [15]. A well-studied molecular mechanism of cold adaptation is the change in lipid composition to maintain membrane fluidity. For example, the chain length of fatty acyl residues can be shortened, or the ratio of unsaturated fatty acyl residues increased (for overview: [16]). Thus adaptation to low temperature is a complex process that manifests itself in gene expression, enzymatic activity, and the structural components of the cell. All these different responses to low temperature as a whole influence growth rates.

With the exception of measurements of growth rates and alterations in cellular fatty acid composition $[10,17$, 18], physiological responses of psychrotolerant sulfatereducing bacteria to changes between low and intermediate temperatures have not been investigated. We have addressed the complexity of responses to temperature changes by profiling protein patterns by two-dimensional gel electrophoresis (2DE) and by measuring activities of complex pathways (sulfate reduction and biosynthesis of fatty acids) with cultures of $D$. autotrophicum strain HRM2. Experiments were performed in a temperature gradient block at temperatures ranging from -1.7 to $43^{\circ} \mathrm{C}$, and with cultures acclimated to three different temperatures $\left(4,10\right.$ and $\left.28^{\circ} \mathrm{C}\right)$.

\section{Materials and methods}

\subsection{Organism and cultivation}

D. autotrophicum strain HRM2 (DSMZ 3382) was obtained from the Deutsche Sammlung von Mikroorganis- men und Zellkulturen, Braunschweig, Germany. Cultivation was performed as originally described by Brysch et al. [13]. The bacterium was grown with lactate $(10 \mathrm{mM})$ as sole source of organic carbon and sulfate as electron acceptor. The mineral medium was sulfide-reduced $(1 \mathrm{mM})$, bicarbonate-buffered, and had essentially the same salt composition as seawater. Methods for anaerobic cultivation were performed as described by Widdel and Bak [19].

\subsection{Growth experiments}

The temperature range of growth was determined in a temperature gradient block. The system consisted of a thermally insulated aluminum block, cooled from one side with a refrigerated circulation thermostat (F34, Julabo, Seelbach, Germany) and heated electrically from the other side [20]. Thermostat and cooling unit were adjusted to achieve a linear temperature gradient from -1.7 to $43^{\circ} \mathrm{C}$. The block contained 28 evenly spaced wells in three parallel rows to hold culture tubes. Cultivation was carried out in glass tubes $(15 \mathrm{ml})$ sealed with butyl rubber septa and screw caps under $\mathrm{N}_{2} / \mathrm{CO}_{2}(90: 10, \mathrm{v} / \mathrm{v})$. Prior to inoculation media were incubated for $24 \mathrm{~h}$ in the temperature gradient block. Cultures were inoculated $(5 \%, \mathrm{v} / \mathrm{v})$ with cells grown at $28^{\circ} \mathrm{C}$. For each of the 28 temperature steps three parallels were conducted. Growth was determined by measuring optical density at $660 \mathrm{~nm}$. Culture tubes were directly placed in a spectrophotometer equipped with a tube holder (UV-1202, Shimadzu, Kyoto, Japan).

Mass cultivation was carried out at 28,10 and $4^{\circ} \mathrm{C}$. Glass bottles (volume of 51 ) containing 41 of medium under $\mathrm{N}_{2} / \mathrm{CO}_{2}(90: 10, \mathrm{v} / \mathrm{v})$ were used for cultivation. Prior to inoculation media were adjusted over 3 days to the respective incubation temperatures. Cultures were inoculated $(5 \%, v / v)$ with fresh cells grown to the exponential phase and acclimated to the respective growth temperature over several passages. Cultures were harvested during the exponential growth phase at an optical density of 0.15 0.18 . During harvesting, the cultures were continuously mixed with a magnetic stirrer to ensure equal cell densities in all samples retrieved and placed in a water bath that was adjusted to the same temperature as that used for cultivation. To ensure that anoxic conditions were maintained during harvesting, the culture bottle was connected to a $\mathrm{N}_{2} / \mathrm{CO}_{2}(90: 10$, v/v) source applying constant pressure of approx. 120 mbar to the surface of the culture. The culture broth was dispensed from the bottle via tubing controlled by a tap. Samples for the determination of sulfate reduction rates (SRR), analysis of fatty acid methyl esters (FAME) and protein patterns were retrieved from the same culture. For measurement of SRR, the culture broth was dispensed in 10-ml portions into glass tubes (15 $\mathrm{ml}$ volume) under a steady stream of $\mathrm{N}_{2} / \mathrm{CO}_{2}$. The tubes were sealed under $\mathrm{N}_{2} / \mathrm{CO}_{2}(90: 10, \mathrm{v} / \mathrm{v})$ with rubber septa and screw caps. 


\subsection{Determination of $S R R$}

SRR were determined in short-term incubations in temperature gradient block experiments. Cultures acclimated to 28,10 and $4{ }^{\circ} \mathrm{C}$, respectively, were incubated in the gradient block [20] at temperatures ranging from -1.7 to $43^{\circ} \mathrm{C}$. The technical details of the gradient block were the same as those used for the determination of the temperature range of growth. For each temperature, duplicate incubations were conducted to determine SRR. A third parallel was used for protein determination. To adjust cells to the individual temperatures, cells were incubated for $1 \mathrm{~h}$ in the temperature gradient block prior to injection of ${ }^{35} \mathrm{SO}_{4}^{2-}$ tracer $(50 \mathrm{kBq}$ total radioactivity in $100 \mu \mathrm{l} 2.5 \%$ $\mathrm{NaCl}$ ). After $4 \mathrm{~h}$ of additional incubation, sulfate reduction was stopped by adding $1 \mathrm{ml}$ zinc acetate $(20 \%$, w/v) to each tube to precipitate all dissolved sulfide as zinc sulfide. The culture tubes were then vortexed for $10 \mathrm{~s}$ and $100-\mu 1$ subsamples of the homogenized culture and precipitate were withdrawn for determination of total ${ }^{35} \mathrm{~S}$ (sulfate plus sulfide) activity. The remaining contents of the culture tube were transferred to a $\mathrm{N}_{2}$-purged distillation apparatus for separation of ${ }^{35}$ sulfide and ${ }^{35}$ sulfate. ${ }^{35}$ Sulfide was acid-distilled with cold $6 \mathrm{~N} \mathrm{HCl}$ and trapped in $5 \%(\mathrm{w} / \mathrm{v})$ zinc acetate. The total trap contents and the 100- $\mu$ l subsamples were counted on a Packard 2500 TR liquid scintillation counter. ${ }^{35} \mathrm{SRR}$ were calculated as the fraction of radioactive sulfide $\left({ }^{35} \mathrm{HS}^{-}\right)$formed relative to total added radioactive $\mathrm{S}\left({ }^{35} \mathrm{HS}^{-}+{ }^{35} \mathrm{SO}_{4}^{2-}\right)$ over the incubation time (h) using the following formula [21]:

${ }^{35} \operatorname{SRR}\left(\right.$ nmol ml ${ }^{-1}$ day $\left.^{-1}\right)=$

$$
\left(\frac{{ }^{35} \mathrm{HS}^{-}}{{ }^{35} \mathrm{HS}^{-}+{ }^{35} \mathrm{SO}_{4}^{2-}}\right) \cdot\left(\mathrm{SO}_{4}^{2-}\right) \cdot\left(\frac{24}{\mathrm{~h}}\right) \cdot 1.021
$$

where $\left(\mathrm{SO}_{4}^{2-}\right)$ is the sulfate concentration and the factor 1.021 represents the isotopic discrimination factor against the heavy isotope ${ }^{35} \mathrm{~S}$ relative to ${ }^{32} \mathrm{~S}$ [22]. In order to relate SRR to the amount of protein as a measure of biomass, volumetric SRR were divided by the concentration of protein in the culture. Average SRR were calculated from the two duplicate incubations. To reduce the analytical scatter of SRR for adjacent temperatures, a moving average over five consecutive values was calculated. We repeated a complete experiment for cultures acclimated to $28^{\circ} \mathrm{C}$, comprising mass cultivation, dispensing of culture broth, and determination of SRR including the determination of protein concentrations. Data from the two experiments were used to calculate the standard deviation in SRR measurements. The average variation in SRR was $13 \%$ or $134 \mathrm{nmol} \mathrm{cm} \mathrm{cm}^{-3}$ $\operatorname{day}^{-1}$.

\subsection{Chemical analysis}

Concentration of protein was determined after Bradford [23] with bovine serum albumin as standard. Samples
( $1 \mathrm{ml})$ of culture broth were centrifuged $(10000 \times \mathrm{g}, 10$ min, $10^{\circ} \mathrm{C}$ ) and cell pellets were stored at $-20^{\circ} \mathrm{C}$ until analysis. Cells were ruptured by repetitive freezing and thawing combined with sonication as described previously [27].

Sulfide was measured in microassays by the methylene blue formation reaction as described previously [24]; sodium sulfide was used as standard. To determine concentrations of sulfate, 1-ml samples were taken with sterile, $\mathrm{N}_{2}$-flushed syringes from the cultures, directly injected into $0.2 \mathrm{ml}$ zinc acetate $(0.5 \%, \mathrm{w} / \mathrm{v})$ and stored at $-20^{\circ} \mathrm{C}$ until further analysis. Concentration of sulfate was quantified by ion conductivity after separation by non-suppressed anion chromatography as described previously [22].

Cellular fatty acids were derivatized to FAME as described by Sasser [25]. Analysis of FAME was carried out by capillary GC-FID and GC-MS measurements as described previously [18]. Cellular fatty acids of sulfatereducing bacteria determined by FAME were recently shown to be representative of phospholipid fatty acids [26].

\subsection{Two-dimensional gel electrophoresis (2DE)}

Approximately 2.51 of culture broth were harvested by centrifugation $\left(10000 \times g, 20 \mathrm{~min}, 10^{\circ} \mathrm{C}\right)$ and washing in $100 \mathrm{mM}$ Tris- $\mathrm{HCl}(\mathrm{pH} 7.5$, containing $5 \mathrm{mM}$ $\mathrm{MgCl}_{2} \cdot 2 \mathrm{H}_{2} \mathrm{O}$ ). Cell pellets (approx. $200 \mathrm{mg}$ wet weight) were rapidly frozen in liquid nitrogen and stored at $-80^{\circ} \mathrm{C}$ until further analysis.

Sample preparation, isoelectric focusing (IEF) and equilibration of IEF gels were carried out essentially as described recently [27]. Cell breakage was performed by sonication using a urea/CHAPS-containing lysis buffer described by Görg et al. [28]. IEF was carried out with commercial 24-cm-long IPG strips ( $\mathrm{pH}$ gradient of 4-7 or non-linear 3-10) using the IPGphor system (Amersham Biosciences, Freiburg, Germany). Protein load for IEF depended on the method applied for staining of gels: 50 $\mu \mathrm{g}$ for silver and $200 \mu \mathrm{g}$ for Sypro ${ }^{\circledR}$ Ruby. Prior to SDSPAGE, IPG strips were equilibrated with DTT- and iodoacetamide-containing buffers [28].

For separation of proteins according to molecular mass the Ettan Dalt II system (Amersham Biosciences) was used. Gels for SDS-PAGE were made of $375 \mathrm{mM}$ TrisBase/Tris- $\mathrm{HCl}, 0.1 \%$ SDS and $12.5 \%$ of the high tensile strength acrylamide, Duracryl [29]. Twelve parallel gels were run at $20^{\circ} \mathrm{C}$ with a running buffer composed of 25 $\mathrm{mM}$ Tris-Base, $192 \mathrm{mM}$ glycine and 0.1\% SDS. Electrophoresis was conducted at $65 \mathrm{~W}$ overnight and stopped when the bromophenol blue marker reached the end of the gel.

Prior to silver staining gels were fixed in an aqueous solution of $40 \%(\mathrm{v} / \mathrm{v})$ ethanol and $10 \%(\mathrm{v} / \mathrm{v})$ glacial acetic acid for $30 \mathrm{~min}$. The fixed gels were sensitized in an aqueous solution of $30 \%(\mathrm{v} / \mathrm{v})$ ethanol, $0.125 \%(\mathrm{w} / \mathrm{v})$ glutaral- 
dehyde, $0.2 \%(\mathrm{w} / \mathrm{v})$ sodium thiosulfate and $10 \%(\mathrm{w} / \mathrm{v})$ sodium acetate pentahydrate for $30 \mathrm{~min}$. Gels were then washed three times for $10 \mathrm{~min}$ in water, followed by incubation in an aqueous mixture of $0.25 \%(\mathrm{w} / \mathrm{v})$ silver nitrate and $1.5 \%$ formaldehyde for $20 \mathrm{~min}$. After the silver reaction, gels were washed in water twice for $1 \mathrm{~min}$. Gels were developed in an aqueous solution of $2.5 \%(\mathrm{w} / \mathrm{v})$ sodium carbonate and $0.75 \%$ formaldehyde. The developing process was stopped after approx. $2-5 \mathrm{~min}$ by incubation in an aqueous solution of $1.5 \%$ sodium EDTA for $10 \mathrm{~min}$. Finally gels were washed three times for 5 min each in water.

To analyze the temperature-regulated abundance of proteins on a more quantitative basis, gels were stained with the fluorescent dye Sypro ${ }^{\circledR}$ Ruby, which is known to possess a wider linear range than silver [37]. Staining with the fluorescent dye Sypro ${ }^{\circledR}$ Ruby was carried out as described recently [27]. For digital analysis, the silverstained gels were scanned with the Image Scanner (Amersham Biosciences). Sypro ${ }^{\circledR}$ Ruby-stained gels were scanned with the fluorescence scanner Typhoon (Amersham Biosciences). Spot identification and quantification were performed using the Image Master 2D software (Amersham Biosciences).

\subsection{Arrhenius plots}

The relation between temperature, growth, and SRR has previously been described by application of the Arrhenius equation $[10,30]$ :

$\ln v=\ln A+\left(\frac{-E_{\mathrm{a}}}{R} \cdot \frac{1}{T}\right)$

where $v$ is the growth or sulfate reduction rate, $A$ is the Arrhenius constant, $R$ is the gas constant and $T$ is the absolute temperature. For chemical reactions, the value of $E_{\mathrm{a}}$ is termed activation energy and is considered constant for a particular reaction. With respect to bacterial growth, the value $E_{\mathrm{a}}(\mu)$ was termed the temperature coefficient [30] and previously shown to be affected by the temperature acclimation of the inoculum [31]. This deviation from the chemical reaction probably reflects the complexity of living cells, where overall rates are not controlled by a single factor.

\section{Results}

\subsection{Growth at different temperatures}

After an incubation of 2 months in the temperature gradient block, minimum and maximum growth temperatures of $D$. autotrophicum strain HRM2 were 1.7 and $31^{\circ} \mathrm{C}$. After an additional 2 months, growth $\left(\mathrm{OD}_{660}\right.$ of at least 0.2 ) was also observed at $0^{\circ} \mathrm{C}$. The Arrhenius plot of growth rates calculated for the exponential growth

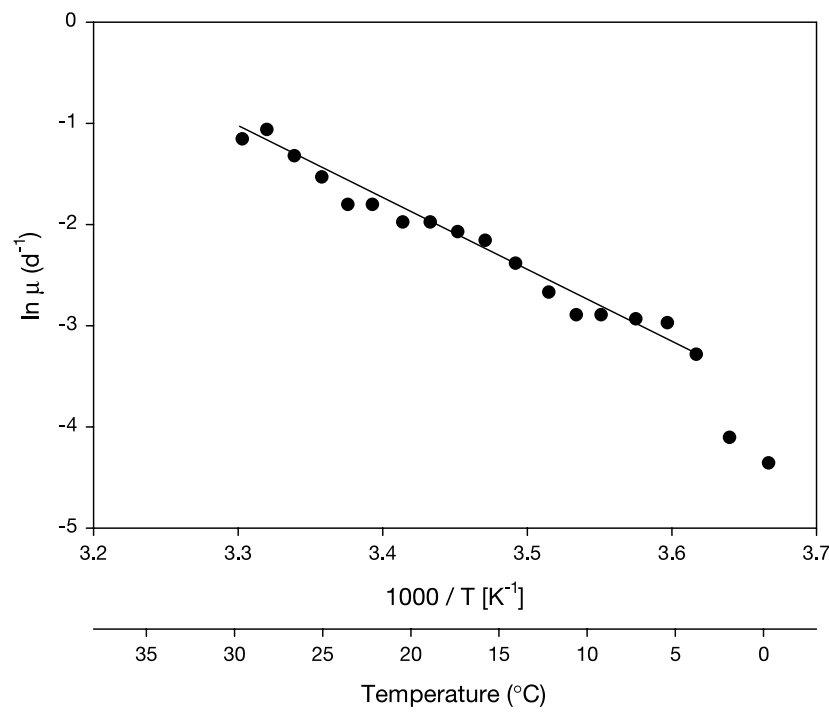

Fig. 1. Arrhenius plot for growth of D. autotrophicum strain HRM2 with lactate as carbon source and sulfate as electron acceptor. Incubation of cultures was carried out in a temperature gradient block.

phase shows that the normal temperature for growth ranges from 29 to $4^{\circ} \mathrm{C}$ (Fig. 1). Above $29^{\circ} \mathrm{C}$ cells grew only slowly and lysed rapidly. Below $4^{\circ} \mathrm{C}$ growth rates decreased more rapidly than within the linear range. The latter is in contrast to psychrophilic sulfate-reducing bacteria that have a linear range extending to temperatures below $0^{\circ} \mathrm{C}[10]$. D. autotrophicum strain HRM2 can clearly be regarded as psychrotolerant, since it grows between 0 $\left(T_{\min }\right)$ and $31^{\circ} \mathrm{C}\left(T_{\max }\right)$. The optimum growth temperature was between 25 and $28^{\circ} \mathrm{C}$, agreeing with earlier results by Brysch et al. [13].

On the basis of the normal temperature range for growth, the temperatures 28,10 , and $4^{\circ} \mathrm{C}$ were selected for the acclimation studies. The temperatures 28 and $4^{\circ} \mathrm{C}$ represent the upper and lower limit of the normal temperature range of growth (Fig. 1). The temperature $10^{\circ} \mathrm{C}$ is typical for coastal environments with high productivity, such as the upwelling region off the coast of Northern America [33]. Hereafter, we refer to such cultures as the $28^{\circ} \mathrm{C}$ culture, the $10^{\circ} \mathrm{C}$ culture, and the $4^{\circ} \mathrm{C}$ culture.

\subsection{Temperature dependence of $S R R$}

SRR increased by a factor of 20 from -1.7 to $41^{\circ} \mathrm{C}$ (Fig. 2). Overall, SRR of cells acclimated to 4 and $10^{\circ} \mathrm{C}$ were very similar; an exception were lower $\mathrm{SRR}$ in the interval between 32 and $40^{\circ} \mathrm{C}$ for the $10^{\circ} \mathrm{C}$ culture. Between -1.7 and $10^{\circ} \mathrm{C}$, all three temperature-acclimated cultures showed a very similar temperature-dependent trend of SRR. However, at the lowest incubation temperature, SRR were slightly higher in the $4^{\circ} \mathrm{C}$ culture than in the $10^{\circ} \mathrm{C}$ or $28^{\circ} \mathrm{C}$ culture. Conversely, at incubation temperatures higher than $10^{\circ} \mathrm{C}$, SRR were higher in the $28^{\circ} \mathrm{C}$ culture than in the $4^{\circ} \mathrm{C}$ or $10^{\circ} \mathrm{C}$ culture. 


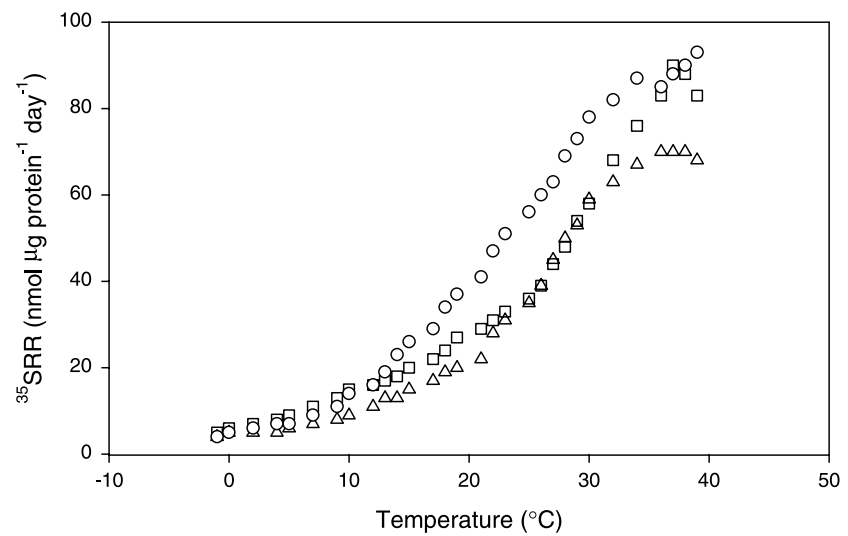

Fig. $2 .{ }^{35} \mathrm{SRR}$ of D. autotrophicum strain HRM2 precultured at different temperatures as determined by short-term incubations in a temperature gradient block. Samples were retrieved from the same cultures used for proteomic (see Figs. 3 and 4, and Table 2) and FAME analysis (Table 1). Cells were grown with lactate at $28^{\circ} \mathrm{C}(\bigcirc), 10^{\circ} \mathrm{C}(\square)$ and $4^{\circ} \mathrm{C}(\Delta)$. The plot displays ${ }^{35} \mathrm{SRR}$ against $T$.

In all cultures SRR were highest between 36 and $40^{\circ} \mathrm{C}$. These temperatures are about $10^{\circ} \mathrm{C}$ higher than the optimum temperature for growth. Similar observations have been reported for other sulfate-reducing bacteria [10,34] and indicate that the temperature-dependent regulation of SRR is not strictly coupled to that of growth as the most complex cellular process.

Independent of the temperature used for acclimating cells, an increase in the incubation temperature by $10^{\circ} \mathrm{C}$ in the gradient block experiment corresponded to a 2-3fold increase in ${ }^{35} \mathrm{SRR}$. This finding is consistent with the

Table 1

Relative amounts of cellular fatty acids (FAME; \%) of D. autotrophicum strain HRM2, incubated at different temperatures

\begin{tabular}{|c|c|c|c|}
\hline \multirow[t]{2}{*}{ FAME } & \multicolumn{3}{|c|}{ Temperature } \\
\hline & $28^{\circ} \mathrm{C}$ & $10^{\circ} \mathrm{C}$ & $4^{\circ} \mathrm{C}$ \\
\hline $14: 1^{\mathrm{a}}$ & 0.3 & 1.1 & 1.8 \\
\hline $14: 0$ & 5.0 & 9.3 & 8.5 \\
\hline $15: 1$ cis 9 & 2.0 & 2.8 & 3.8 \\
\hline $15: 0$ & 1.8 & 2.4 & 3.2 \\
\hline $16: 1$ cis 7 & 0.5 & 1.3 & 1.5 \\
\hline $16: 1$ cis 9 & 52.0 & 57.2 & 53.0 \\
\hline $16: 1$ cis 11 & 1.7 & 1.6 & 1.6 \\
\hline $16: 0$ & 12.3 & 7.0 & 6.9 \\
\hline $16: 010 \mathrm{Me}$ & 5.2 & 0.1 & 0.9 \\
\hline $17: 1$ cis 11 & 3.2 & 4.6 & 6.9 \\
\hline 17:0 anteiso & 0.6 & 0.8 & 1.2 \\
\hline $17: 0$ & 0.6 & 0.2 & 0.3 \\
\hline $18: 1$ cis 9 & 0.6 & 0.3 & 0.3 \\
\hline 18:1 cis 11 & 4.4 & 2.2 & 2.3 \\
\hline \multicolumn{4}{|l|}{ Sum } \\
\hline Unidentified $^{\mathrm{b}}$ & 5.7 & 4.8 & 3.9 \\
\hline Unsaturated $^{\mathrm{c}}$ & 64.6 & 71.1 & 71.1 \\
\hline Short chain $(<16 \mathrm{C}$-atoms $)$ & 9.1 & 15.6 & 17.3 \\
\hline Branched $^{c}$ & 5.8 & 1.4 & 2.7 \\
\hline
\end{tabular}

FAMEs present at all temperatures at less than $1 \%$ are not listed.

${ }^{\text {a }}$ Position of double bond was not determined.

${ }^{b}$ In Vainshtein et al. [42] described as 15:0 dimethyl acetal.

${ }^{\mathrm{c}}$ Calculated for all identified FAMEs.
Table 2

Temperature-dependent protein synthesis in D. autotrophicum strain HRM2 as determined by Sypro ${ }^{\circledR}$ Ruby-stained 2DE gels

\begin{tabular}{lllr}
\hline Protein spot $^{\mathrm{a}}$ & \multicolumn{2}{l}{ Amount of protein $(\mu \mathrm{g})$ per spot $^{\mathrm{b}}$} & \multirow{2}{*}{ Ratio $^{\mathrm{c}}$} \\
\cline { 2 - 3 } & $28^{\circ} \mathrm{C}^{\mathrm{d}}$ & $4^{\circ} \mathrm{C}^{\mathrm{d}}$ & \\
\hline 1 & 1.07 & 0.95 & 1.13 \\
2 & 1.66 & 0.15 & 11.07 \\
3 & 1.69 & 2.46 & 0.69 \\
4 & 2.33 & 3.89 & 0.60 \\
5 & 0.53 & 0.11 & 4.82 \\
6 & 1.07 & 1.56 & 0.66 \\
\hline
\end{tabular}

a Numbering of protein spots corresponds to the one used in Fig. 4. ${ }^{b}$ Calculation of the amount of protein per spot was based on the sum of spot volumes per gel determined by analysis of gels with the Image Master 2D software and the total protein load per gel of $200 \mu \mathrm{g}$. Each value represents the average from $2-3$ corresponding spots identified in parallel gels.

${ }^{\mathrm{c}}$ Ratio of protein amounts related to growth temperatures of 28 and $4^{\circ} \mathrm{C}$.

${ }^{\mathrm{d}}$ Protein mixtures analyzed by $2 \mathrm{DE}$ were obtained from cultures of D. autotrophicum strain HRM2 grown at 28 or $4^{\circ} \mathrm{C}$. The same cultures were used for measurement of SRR (Fig. 2) and FAME (Table 1).

temperature adaptation of metabolic activities known from Pseudomonas species, Escherichia coli, Salmonella, and other psychrotolerant sulfate-reducing bacteria [10, $32,35]$.

\subsection{Temperature dependence of fatty acid composition}

The cellular fatty acid compositions of $D$. autotrophicum grown at 28,10 , and $4^{\circ} \mathrm{C}$ are summarized in Table 1 . Hexadecenoic acid (cis9 16:1), hexadecanoic acid (16:0) and the branched 10-methylhexadecanoic acid (10Me16:0) were predominant in the $28^{\circ} \mathrm{C}$ culture. 16:0 and 10Me16:0 were lower in the $10^{\circ} \mathrm{C}$ and $4^{\circ} \mathrm{C}$ cultures, whereas the sum of unsaturated fatty acids $(>70 \%)$ increased relative to the $28^{\circ} \mathrm{C}$ culture. In addition, the relative amount of short-chain fatty acids ( $<16 \mathrm{C}$-atoms) increased when cells were grown at 4 and $10^{\circ} \mathrm{C}$.

\subsection{Influence of temperature on protein patterns}

Irrespective of the growth temperature, the overall protein patterns were very similar, when non-linear $\mathrm{pH}$ gradients of 3-10 (data not shown) or 4-7 (Fig. 3) were used. We focused our investigation on the $\mathrm{pH}$ range of 4-7, since the majority of proteins separable in the wide $\mathrm{pH}$ gradient of 3-10 were in fact localized in the $\mathrm{pH}$ range of 4-7, where a superior resolution is possible. This observation has also been reported for well-studied $E$. coli, with more than $90 \%$ of the abundant proteins being resolved in this $\mathrm{pH}$ window [36]. The silver-stained gels shown in Fig. 3 resolved about 250 protein spots, which appeared to be present at similar levels at all three temperatures. However, two proteins of low molecular mass appeared to be less abundant, when cells were grown at 10 or $4^{\circ} \mathrm{C}$ as compared to $28^{\circ} \mathrm{C}$. These two proteins are centered in 

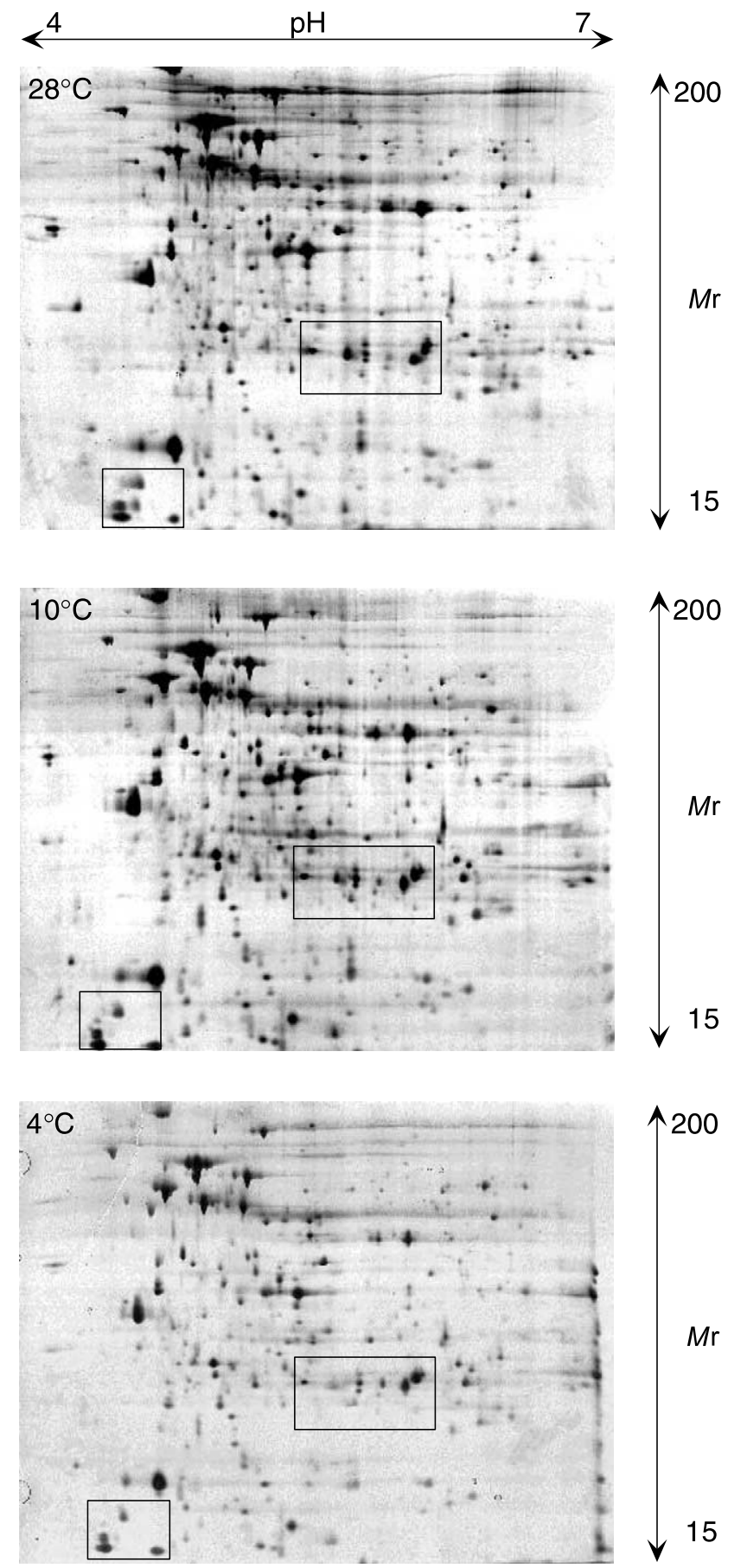

Fig. 3. Partial views of the proteome of $D$. autotrophicum strain HRM2 reflecting growth at different temperatures, as revealed by 2DE. Gels were stained with silver and the protein load was $50 \mu \mathrm{g}$. Samples were retrieved from the same cultures used for SRR (see Fig. 2) and FAME analysis (Table 1). Cells were grown with lactate at $28^{\circ} \mathrm{C}, 10^{\circ} \mathrm{C}$ and $4^{\circ} \mathrm{C}$. Boxed areas (I and II) contain proteins that are less abundant at low temperatures. Selected proteins that were further analysed (see Fig. 4 and Table 2) are marked by arrows and numbers.

the boxed areas of Fig. 3. Partial views of the Sypro ${ }^{\circledR}$ Ruby-stained gels are shown in Fig. 4 and correspond to the boxed areas of the silver-stained gels in Fig. 3. Protein spots 2 and 5 clearly contained lower amounts of proteins in the gels from the $4^{\circ} \mathrm{C}$ culture than in the gels from the $28^{\circ} \mathrm{C}$ culture, when staining was carried out with the quantitatively more accurate Sypro ${ }^{\circledR}$ Ruby stain. The amounts of protein in spots 2 and 5 decreased by a factor of 11 and 5 , respectively, while the protein amounts in neighbouring spots $1,3,4$ and 6 varied by less than a factor of 1.6 (Table 2).

\section{Discussion}

Temperature is an important physicochemical parameter relevant for all biological systems [38]. Two opposing strategies are conceivable for living cells to adapt to changes in temperature. To maintain metabolic activities at constant levels, multiple adaptive changes would be required at all molecular levels. A less energy-demanding mode of adaptation would be the ability to survive at overall reduced metabolic rates with the minimum necessary number of changes in protein synthesis and molecular composition of the cell.

Comprehensive biochemical/metabolic changes are generally based on fundamental alterations in gene expression. We studied global gene expression in D. autotrophicum strain HRM2 at the level of synthesized proteins by 2DE. Protein patterns indicated that with the exception of two proteins, which were less abundant at 10 and $4^{\circ} \mathrm{C}$ relative to $28^{\circ} \mathrm{C}$ (Figs. 3 and 4), the overall protein pattern did not change in response to temperature changes. For these two proteins, a clear distinction between either decrease or increase of abundance in response to low $\left(4^{\circ} \mathrm{C}\right)$ or intermediate $\left(28^{\circ} \mathrm{C}\right)$ temperatures is not possible. Completion of the $D$. autotrophicum genome sequence will enable us to identify the genes coding for the two temperature-controlled proteins and to relate the number of 2DE-separable proteins to the number of predicted genes.

In marine sediments of temperate climates, transitions between cold and intermediate temperatures are gradual and may permit the microbial community to gradually adapt as environmental temperature changes. Possibly, D. autotrophicum possesses proteins with a wide temperature range of activity that allow growth at low temperature without an energy-demanding alteration of the set of functional proteins. Proteins that are active at both intermediate and low temperatures are usually more thermolabile than their truly mesophilic counterparts. This could explain the abrupt loss of viability, the short stationary phase, and the high rates of cellular death close to $T_{\max }$ $\left(31^{\circ} \mathrm{C}\right)$. This contrasts strongly with the growth behavior at the lower end of the temperature range.

D. autotrophicum strain HRM2 generates energy by coupling the oxidation of organic substrate to the dissimilatory reduction of sulfate to sulfide. The 20 -fold reduction in SRR from the highest to the lowest temperature could result from reduced substrate turnover of catabolic enzymes or of enzymes involved in the dissimilatory reduction of sulfate. Reduced substrate affinities and/or cat- 

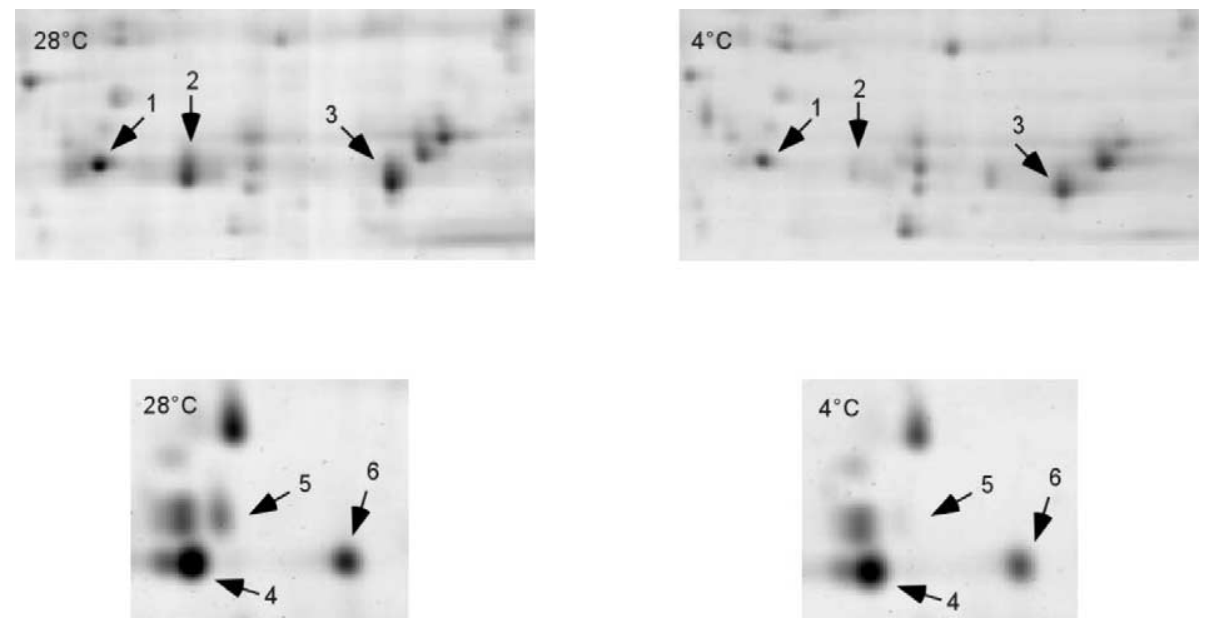

Fig. 4. Detailed view of the proteome of $D$. autotrophicum strain HRM2 revealing the lower abundance of proteins at low temperatures. Cells were grown with lactate at $28^{\circ} \mathrm{C}$ and $4^{\circ} \mathrm{C}$. Shown sections of $2 \mathrm{DE}$ gels correspond to the boxed areas in Fig. 3. The protein load per gel was $200 \mu \mathrm{g}$ and gels were stained with the fluorescent dye Sypro ${ }^{\circledR}$ Ruby. Protein amounts of spots marked with arrows and numbers are given in Table 2.

alytic activities would be in agreement with the absence of de novo protein synthesis as discussed above. Another explanation would be less efficient coupling of electron transfer between substrate oxidation and sulfate reduction at low temperature. The latter assumption is in agreement with the observation that mesophilic marine bacteria have lower growth efficiencies at low temperature [39]. With respect to SRR, the $28^{\circ} \mathrm{C}$ culture was better adapted to intermediate temperatures $\left(10-25^{\circ} \mathrm{C}\right)$ than the $4^{\circ} \mathrm{C}$ and $10^{\circ} \mathrm{C}$ cultures. It appears that acclimation to low temperature does not fully compensate for the thermodynamic restrictions imposed on complex biochemical processes such as respiratory energy generation.

Maintenance of membrane fluidity is required for the structural integrity of the cell and for the functionality of membrane-associated processes such as respiratory energy generation. The cellular fatty acid composition of $D$. autotrophicum at optimal temperature is comparable to the composition described for other sulfate-reducing bacteria [40]. The characteristic fatty acid 10Me16:0, often described as an SRB-specific biomarker [41], was only found in significant amounts at mesophilic conditions. Cold inhibition of 10Me16:0 formation has also been found in species of the genus Desulfobacter [18]. A change in the ratio of saturated to unsaturated fatty acids is the most frequently described regulation of membrane fluidity in bacteria [42]. At low temperature, the increase in unsaturated fatty acids in the membrane fraction leads to an increase in fluidity, which is essential for a number of membrane-coupled functions. The relative amounts of unsaturated fatty acids and the temperature-dependent changes in D. autotrophicum were comparable to those reported for psychrotolerant Pseudomonas species [43]. Although the total amount of unsaturated fatty acids in D. autotrophicum grown at low temperature was more than $70 \%$, this amount is still less than that found in psychrophilic sulfate-reducing bacteria (more than $80 \%$; see $[12,18])$. A similar effect has been described for the incorporation of fatty acids with shorter acyl chains [16].

\section{Conclusions}

D. autotrophicum strain HRM2 modulated the levels of overall cellular activities in response to temperature without pronounced alterations in protein composition. The most significant change in cellular activities was observed in the temperature gradient block experiment when SRR decreased in the normal range of temperature for growth $\left(29-4^{\circ} \mathrm{C}\right)$ by a factor of about 20 . Apparently, this bacterium possesses enzymes with activity ranges that permit metabolism in the moderately warm to cold temperature range. The temperature range investigated in this study corresponds well to seasonal temperature variations observed in near-shore temperate marine environments such as intertidal flats and lagoons. Interestingly, the range of SRR measured with $D$. autotrophicum strain HRM2 in the temperature gradient block is similar to that determined by in situ measurements over seasonal cycles in sediments of estuaries, salt marshes, and lagoons from temperate environments [44-46]. The physiological response of $D$. autotrophicum strain HRM2 to temperature changes may therefore be regarded as representative of many other psychrotolerant bacteria isolated from these environments. Furthermore, since psychrotolerance of this bacterium was only recognized after prolonged incubation, one may speculate that other isolates of sulfatereducing bacteria from temperate marine sediments so far considered mesophilic may in fact also be psychrotolerant.

\section{Acknowledgements}

We thank Friederike Heinrich, Daniela Lange, Anne 
Mai-Prochnow, Christina Probian, Pirrko Stübner, and Lars Wöhlbrandt for technical assistance. This work was supported by the BMBF and by the Max-Planck Society.

\section{References}

[1] Nedwell, D.B. (1999) Effect of low temperature on microbial growth: lowered affinity for substrates limits growth at low temperature. FEMS Microbiol. Ecol. 30, 101-111.

[2] Sagemann, J., Skowronek, F., Dahmke, A. and Schulz, H.D. (1996) Pore-water response on seasonal environmental changes in intertidal sediments of the Weser Estuary, Germany. Environ. Geol. 27, 362369.

[3] Wiegel, J. (1990) Temperature spans for growth: hypothesis and discussion. FEMS Microbiol. Rev. 75, 155-170.

[4] Berner, R.A. (1989) Biogeochemical cycles of carbon and sulfur and their effect on atmospheric oxygen over phanerozoic time. Paleogeogr. Paleoclimatol. Palaeoecol. 75, 97-122.

[5] Jørgensen, B.B. (1982) Mineralization of organic matter in the sea bed - the role of sulphate reduction. Nature 296, 643-645.

[6] Canfield, D.E., Jørgensen, B.B., Fossing, H., Glud, R., Gundersen, J., Ramsing, N.B., Thamdrup, B., Hansen, J.W., Nielsen, L.P. and Hall, P.O.J. (1993) Pathways of organic carbon oxidation in three continental margin sediments. Mar. Geol. 113, 27-40.

[7] Widdel, F. (1988) Microbiology and ecology of sulfate-reducing bacteria. In: Biology of Anaerobic Microorganisms, Vol. 3 (Zehnder, A.J.B., Ed.), pp. 469-585. Carl Hanser Verlag, Munich.

[8] Rabus, R., Hansen, T.A. and Widdel, F. (2000) Dissimilatory sulfateand sulfur-reducing prokaryotes. In: The Prokaryotes: an Evolving Electronic Resource for the Microbiological Community (Dworkin, M., Falkow, S., Rosenberg, E., Schleifer, K.-H. and Stackebrandt, E., Eds.). Heidelberg, Springer Science Online (www.prokaryotes. com).

[9] Widdel, F. (1987) New types of acetate-oxidizing, sulfate-reducing Desulfobacter species, D. hydrogenophilus sp. nov., D. latus sp. nov., and D. curvatus sp. nov.. Arch. Microbiol. 148, 286-291.

[10] Isaksen, M.F. and Jørgensen, B.B. (1996) Adaptation of psychrophilic and psychrotrophic sulfate-reducing bacteria to permanently cold marine environments. Appl. Environ. Microbiol. 62, 408-414.

[11] Motamedi, M. and Pedersen, K. (1998) Desulfovibrio aespoeensis sp. nov., a mesophilic sulfate-reducing bacterium from deep groundwater at Äspö hard rock laboratory, Sweden. Int. J. Syst. Bacteriol. 48, 311-315.

[12] Knoblauch, C., Sahm, K. and Jørgensen, B.B. (1999) Psychrophilic sulfate-reducing bacteria isolated from permanently cold Arctic marine sediments: description of Desulfofrigus oceanense gen. nov., sp. nov., Desulfofrigus fragile sp. nov., Desulfofaba gelida gen. nov., sp. nov., Desulfotalea psychrophila gen. nov., sp. nov. and Desulfotalea arctica sp. nov.. Int. J. Syst. Bacteriol. 49, 1631-1643.

[13] Brysch, K., Schneider, C., Fuchs, G. and Widdel, F. (1987) Lithoautotrophic growth of sulfate-reducing bacteria, and description of Desulfobacterium autotrophicum gen. nov., sp. nov.. Arch. Microbiol. 148, 264-274.

[14] Jaenicke, R. (1990) Protein structure and function at low temperature. Philos. Trans. R. Soc. London Ser. B Biol. Sci. 326, 535-553.

[15] Hébraud, M. and Potier, P. (1999) Cold shock response and low temperature adaptation in psychrotrophic bacteria. J. Mol. Microbiol. Biotechnol. 1, 211-219.

[16] Russell, N.J. (1990) Cold adaptation of microorganisms. Philos. Trans. R. Soc. London Ser. B Biol. Sci. 326, 595-611.

[17] Sass, H., Berchtold, M., Branke, J., König, H., Cypionka, H. and Babenzien, H.-D. (1998) Psychrotolerant sulfate-reducing bacteria from an oxic freshwater sediment, description of Desulfovibrio cuneatus sp. nov. and Desulfovibrio litoralis sp. nov.. Syst. Appl. Microbiol. 21, 212-219.
[18] Könneke, M. (2001) Untersuchungen der zellulären Fettsäuren von sulfatreduzierenden Bakterien aus kalten, marinen Sedimenten. PhD Thesis, University Bremen.

[19] Widdel, F. and Bak, F. (1992) Gram-negative mesophilic sulfate-reducing bacteria. In: The Prokaryotes, 2nd edn. (Balows, A., Trüper, H.G., Dworkin, M., Harder, W. and Schleifer, K.-H., Eds.), pp. 583624. Springer-Verlag, New York.

[20] Sagemann, J., Jørgensen, B.B. and Greeff, O. (1998) Temperature dependence and rates of sulfate reduction in cold sediments of Svalbard, Arctic Ocean. Geomicrobiol. J. 15, 85-100.

[21] Fossing, H. (1995) ${ }^{35} \mathrm{~S}$-Radiolabelling to probe biogeochemical cycling. In: Geochemical Transformations of Sedimentary Sulfur, Vol. 612 (Variavamurthy, M.A. and Schoonen, M.A., Eds.), pp. 248-364. American Chemical Society, Washington, DC.

[22] Brüchert, V., Knoblauch, C. and Jørgensen, B.B. (2001) Controls on stable sulfur isotope fractionation during bacterial sulfate reduction in Arctic sediments. Geochim. Cosmochim. Acta 65, 763-776.

[23] Bradford, M.M. (1976) A rapid and sensitive method for the quantitation of microgram quantities of protein utilizing the principle of protein-dye binding. Anal. Biochem. 72, 248-254.

[24] Aeckersberg, F., Bak, F. and Widdel, F. (1991) Anaerobic oxidation of saturated hydrocarbons to $\mathrm{CO}_{2}$ by a new type of sulfate-reducing bacterium. Arch. Microbiol. 156, 5-14.

[25] Sasser, M. (1997) Identification of bacteria by gas chromatography of cellular fatty acids. Technical Note 101 MIDI Sherlock.

[26] Rütters, H., Sass, H., Cypionka, H. and Rullkötter, J. (2001) Monoalkylether phospholipids in the sulfate-reducing bacteria Desulfosarcina variabilis and Desulforhabdus amnigenus. Arch. Microbiol. 176, 435-442.

[27] Rabus, R., Gade, D., Helbig, R., Bauer, M., Glöckner, F.O., Kube, M., Reinhardt, R. and Amann, R. (2002) Analysis of $N$-acetylglucosamine metabolism in the marine bacterium Pirellula sp. strain 1 by a proteomic approach. Proteomics 2, 649-655.

[28] Görg, A., Obermaier, C., Boguth, G., Harder, A., Scheibe, B., Wildgruber, R. and Weiss, W. (2000) The current state of two-dimensional electrophoresis with immobilized $\mathrm{pH}$ gradients. Electrophoresis 21, 1037-1053.

[29] Patton, W.F., Lopez, M.F., Barry, P. and Shea, W.M. (1992) A mechanically strong matrix for protein electrophoresis with enhanced silver staining properties. BioTechniques 12, 580-585.

[30] Ingraham, J.L. (1958) Growth of psychrophilic bacteria. J. Bacteriol. 76, 75-80.

[31] Reichardt, W. and Morita, R.Y. (1982) Temperature characteristics of psychrotrophic and psychrophilic bacteria. J. Gen. Microbiol. 128, $565-568$.

[32] Ingraham, J.L. and Marr, A.G. (1996) Effect of temperature, pressure, $\mathrm{pH}$, and osmotic stress on growth. In: Escherichia coli and Salmonella. Cellular and Molecular Biology, 2nd edn. (Neidhardt, F.C., Curtiss III, R., Ingraham, J.L., Lin, E.C.C., Low, K.B., Magasanik, B., Reznikoff, W.S., Riley, M., Schaechter, M. and Umbarger, H.E., Eds.), pp. 1570-1578. ASM Press, Washington, DC.

[33] Hermann, A.J., Hickey, B.M., Landry, M.R. and Winter, D.F. (1986) Coastal upwelling dynamics. In: Coastal Oceanography of Washington and Oregon (Landry, M.R. and Hickey, B.M., Eds.), pp. 211253. Elsevier, Amsterdam.

[34] Knoblauch, C. and Jørgensen, B.B. (1999) Effect of temperature on sulphate reduction, growth rate and growth yield in five psychrophilic sulphate-reducing bacteria from Arctic sediments. Environ. Microbiol. 1, 457-467.

[35] Harder, W. and Veldkamp, H. (1968) Physiology of obligate psychrophilic marine Pseudomonas species. J. Appl. Bacteriol. 31, 12-23.

[36] Link, A.J., Robison, K. and Church, G.M. (1997) Comparing the predicted and observed properties of proteins encoded in the genome of Escherichia coli K-12. Electrophoresis 18, 1259-1313.

[37] Lopez, M.F., Berggren, K., Chernokalskaya, E., Lazarev, A., Robinson, M. and Patton, W.F. (2000) A comparison of silver stain and SYPRO Ruby Protein Gel Stain with respect to protein detection in 
two-dimensional gels and identification by peptide mass profiling. Electrophoresis 21, 3673-3683.

[38] Franks, F., Mathias, S.F. and Hatley, R.H.M. (1990) Water, temperature and life. Philos. Trans. R. Soc. London Ser. B Biol. Sci. 326, $517-533$.

[39] Wiebe, W.J., Sheldon Jr., W.M. and Pomeroy, L.R. (1992) Bacterial growth in the cold: evidence for an enhanced substrate requirement. Appl. Environ. Microbiol. 58, 359-364.

[40] Vainshtein, M., Hippe, H. and Kroppenstedt, R.M. (1992) Cellular fatty acid composition of Desulfovibrio species and its use in classification of sulfate-reducing bacteria. Syst. Appl. Microbiol. 15, 554 556.

[41] Findlay, R.H. and Dobbs, F.C. (1993) Quantitative description of microbial communities using lipid analysis. In: Handbook of Methods in Aquatic Microbial Ecology (Kemp, P., Ed.), pp. 271-284. Lewis Publishers, Boca Raton, FL.
[42] Gounot, A.M. and Russel, N.J. (1999) Physiology of cold-adapted microorganisms. In: Cold-adapted Organisms (Margesin, R. and Schinner, F., Eds.), pp. 33-55. Springer Verlag, New York.

[43] Bhakoo, M. and Herbert, R.A. (1980) Fatty acid and phospholipid composition of five psychrotrophic Pseudomonas spp. grown at different temperatures. Arch. Microbiol. 126, 51-55.

[44] Jørgensen, B.B. (1977) The sulfur cycle of a coastal marine sediment (Limfjorden, Denmark). Limnol. Oceanogr. 22, 814-832.

[45] Nedwell, D.B. and Abram, J.W. (1978) Bacterial sulphate reduction in relation to sulphur geochemistry in two contrasting areas of salt marsh sediment. Estuar. Coast. Mar. Sci. 6, 341-351.

[46] Martens, C.S. and Klump, V. (1984) Biogeochemical cycling in an organic-rich sediment 4 . An organic carbon budget for sediments dominated by sulfate reduction and methanogenesis. Geochim. Cosmochim. Acta 48, 1987-2004. 